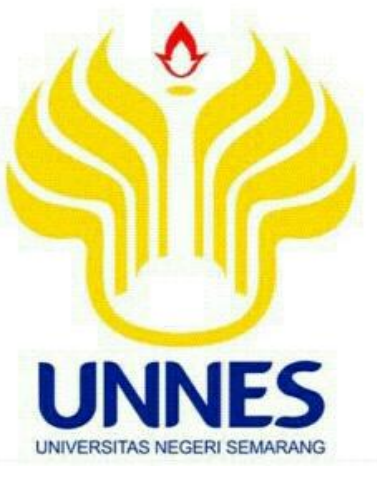

\title{
PEMBELAJARAN SENI TARI DENGAN MENGGUNAKAN MEDIA AUDIO VISUAL PADA SISWA KELAS VII D DI SMP NEGERI 1 MLONGGO
}

\section{JURNAL}

untuk mencapai gelar Sarjana Pendidikan

\begin{tabular}{ll} 
& \multicolumn{1}{c}{ oleh: } \\
Nama & $:$ Bernike Marlinda \\
NIM & $: 2501409079$ \\
Program Studi & $:$ Pendidikan Seni Tari \\
Jurusan & $:$ Pendidikan Sendratasik
\end{tabular}

FAKULTAS BAHASA DAN SENI

UNIVERSITAS NEGERI SEMARANG

2016 


\section{NASKAH PUBLIKASI}

\section{PEMBELAJARAN SENI TARI DENGAN MENGGUNAKAN MEDIA AUDIO VISUAL PADA SISWA KELAS VII D DI SMP NEGERI 1 MLONGGO}

Yang dipaparkan dan disusun oleh

Bernike Marlinda

2501409079

Telah disetujui oleh

Pembimbing,

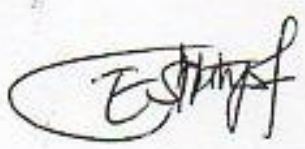

Dra. Eny Kusumastuti, M.Pd

NIP. 196804101993032001

Tanggal, 25 Agustus 2016 


\title{
PEMBELAJARAN SENI TARI DENGAN MENGGUNAKAN MEDIA AUDIO VISUAL PADA SISWA KELAS VII D DI SMP NEGERI 1 MLONGGO
}

\author{
Bernike Marlinda, Hartono, Eny Kusumastuti, \\ Program Studi Pendidikan Seni Tari S1 \\ Fakultas Bahasa Dan Seni \\ Universitas Negeri Semarang
}

\begin{abstract}
SARI
Pembelajaran Seni Tari Dengan Menggunakan Media Audio Visual Pada Siswa Kelas VII D Di SMP Negeri 1 Mlonggo merupakan pembelajaran seni budaya khususnya seni tari dalam memanfaatkan pentingnya penggunaan media pembelajaran sebagai faktor penunjang pembelajaran berjalan secara maksimal. Rumusan masalah dalam penelitian ini adalah: Bagaimanakah proses pembelajaran seni tari dengan menggunakan media audio visual pada siswa kelas VII D di SMP Negeri 1 Mlonggo?. Tujuan dalam penelitian ini adalah: Menjelaskan proses pembelajaran seni tari dengan menggunakan media audio visual pada siswa kelas VII D di SMP Negeri 1 Mlonggo. Penelitian ini menggunakan metode kualitatif dengan pendekatan pedagogik. Teknik pengumpulan data yang digunakan dalam penelitian ini adalah observasi, wawancara, dokumentasi dan analisis data. Pada teknik analisis data peneliti menggunakan tiga alur kegiatan yang harus dilakukan yaitu: mereduksi data, menyajikan data, serta menarik kesimpulan dalam proses pembelajaran yang berlangsung. Hasil penelitian ini menunjukkan bahwa siswa kelas VII D SMP Negeri 1 Mlonggo melaksanakan proses pembelajaran dengan 3 tahap yaitu: 1) Persiapan terdiri dari Silabus dan RPP, 2) Pelaksanaan Proses Belajar Mengajar terdiri dari peserta didik, guru, tujuan pembelajaran, proses pembelajaran, langkah-langkah pembelajaran, metode pembelajaran, media pembelajaran, kurikulum, bahan pembelajaran, dan ruang pembelajaran yang kondusif, 3) Pelaksanaan Proses Belajar Mengajar dengan menggunakan media audio visual terdiri dari: pembukaan, inti, dan penutup. Pelaksanaan 3 tahap dalam proses belajar mengajar seni tari dengan media audio visual peserta didik mampu menguasai materi dengan lebih mudah. Saran terkait penelitian yang sudah dilakukan yaitu penggunaan media audio visual sebagai salah satu variasi guru dalam menyampaikan materi pelajaran ditanggapi dengan baik oleh para siswa dan memotivasi mereka untuk lebih menyukai pembelajaran seni tari sehingga rasa cinta terhadap kebudayaan daerah lebih meningkat.
\end{abstract}

Kata kunci : Pembelajaran Seni Tari, Media Audio Visual

\begin{abstract}
Learning the art of dance by using audio visual media in class VII D in SMP Negeri 1 Mlonggo a learning culture especially the art of dance in the use of learning the importance of using the media as a factor supporting the learning run optimally. Formulation of the problem in this research is: how the process of learning the art of dance by using audio visual media in class VII D in SMP Negeri 1 Mlonggo?. The purpose of this research is: to explain the process of learning the art of dance by using audio visual media in class VII D in SMP Negeri 1 Mlonggo. The result of this study used qualitative methods on the pedagogy. Data collection technique used in this research is observation, interview, documentation, and data analysis. On data analysis techniques researchers used three grooves activities that must be done is to reduce the data, presenting data, and to drwa conclusions in the learning process that takes place. This study has shown that student of class VII D in SMP Negeri 1 Mlonggo implement the learning process with 3 strages: 1) Preparation consists of a Syllabus and RPP, 2) The implementation of the teaching and learning process is composed of student, teachers,learning objectives, the learning process, the steps of learning, teaching methods, instructional media, curriculum, instructional materials, and a conducive learning space, 3) The implementation of the teaching and learning process by using audio visual media consist of opening, the core, and the cover. Implementation of the 3 stages in the process of learning the art of dance by using audio visual media student were able to master the material more easily. Advice related to the research that has been done is the use of audio visual media as one variation of the teacher in delivering the subject matter well received by the students and motivate them to be more like learning the art of dance to a love of local culture is increased.
\end{abstract}

Keywords: Learning Dance, Audio Visual Media 


\section{PENDAHULUAN}

Pendidikan adalah salah satu usaha untuk mewujudkan suasana belajar dan proses pembelajaran agar peserta didik aktif mengembangkan potensi dirinya untuk memiliki kepribadian, kecerdasan, pengendalian diri serta ketrampilan yang diperlukan dirinya. Sekolah merupakan pendidikan formal yang sistematik melaksanakan program bimbingan, pengajaran, dan latihan dalam rangka membantu siswa agar mampu mengembangkan potensinya, baik yang menyangkut aspek moral, spiritual, intelektual, emosional, maupun sosial. Proses belajar mengajar merupakan kegiatan utama dalam pengajaran. Proses belajar dan mengajar terdiri dari beberapa komponen utama antara lain siswa, guru, tujuan, bahan, metode, media, dan evaluasi. Komponen tersebut dalam pelaksanaannya saling terkait satu sama lain, ketika salah satu komponen diabaikan maka hasil proses belajar tidak tercapai secara optimal.

Pembelajaran seni budaya terbagi dalam beberapa cabang seni, salah satunya adalah seni tari. Pelaksanaanya, pembelajaran dapat menggunakan dua strategi yaitu strategi formal dan strategi informal (Soetopo 2004:49). Strategi formal dalam pembelajaran dilakukan dengan sengaja, sistematis, terencana, dalam suasana resmi serta berlangsung di kelas atau tempat tertentu. Strategi ini di dalam pembelajaran seni tari dapat berlangsung di kelas, ruang tari, aula, dan sanggar. Strategi nonformal dalam belajar adalah strategi yang dilakukan tanpa anjuran guru. Siswa dengan kemauannya sendiri belajar menari. Siswa dengan kesadaran dan dedikasi yang tinggi mau belajar. Pembelajaran yang telah mencapai tahap ini, jika didalam diri siswa sudah terjadi proses internalisasi (penghayatan) sampai pada tahap mencintai dan bersedia melakukan sesuatu.

Pembelajaran seni tari pada umumnya yang dilakukan di sekolah dengan menggunakan metode meniru gerakan yang diberikan oleh guru. Model pembelajaran seperti ini dilakukan oleh para guru seni tari termasuk di SMP Negeri 1 Mlonggo karena yang diharapkan siswa dapat lebih mudah menerima materi satu tarian dengan cara menirukan dan menghafal gerak-gerak tari yang sudah diajarkan, dalam hal ini sumber utama dalam pembelajaran adalah guru.

Sekolah Menengah Pertama (SMP) Negeri 1 Mlonggo adalah SMP yang menjadikan pembelajaran seni tari salah satu bagian dalam pembelajaran seni budaya. Pembelajaran seni tari setiap minggunya mendapatkan waktu pembelajaran selama $2 \times 35$ menit. Ruang pembelajaran untuk seni tari adalah di ruang kelas dan ruang praktek. Ruang praktek yang telah dibuat khusus untuk praktek pembelajaran seni tari seharusnya cukup untuk melakukan pembelajaran praktek siswa satu kelas, akan tetapi karena SMP Negeri 1 Mlonggo mendapat bantuan gamelan, maka ruang praktek yang dapat digunakan hanya setengah ruangan saja.

Metode pembelajaran yang digunakan oleh guru pengampu mata pelajaran seni tari tidak hanya berdasar semata-mata dari cara penyampaian materi saja, melainkan penggunaan media sebagai pendukung dalam pembelajaran sangat besar 
pengaruhnya terhadap respon siswa. Penggunaan media pembelajaran memiliki manfaat dalam pembelajaran, menurut (Sudjana dan Rivai 1992:2 dalam Arsyad 2008: 24-25), yaitu: pembelajaran akan lebih menarik perhatian siswa sehingga dapat menumbuhkan motivasi belajar; bahan pembelajaran akan lebih jelas maknanya sehingga dapat lebih dipahami oleh siswa dan memungkinkannya menguasai dan mencapai tujuan pembelajarannya; metode mengajar akan lebih bervariasi, tidak semata-mata komunikasi verbal melalui penuturan kata-kata oleh guru, sehingga siswa tidak bosan dan guru tidak kehabisan tenaga, apalagi kalau guru mengajar pada setiap jam pelajaran; siswa dapat lebih banyak melakukan kegiatan belajar sebab tidak hanya mendengarkan uraian guru, tetapi juga aktivitas lain seperti mengamati, melakukan, mendemonstrasikan dan memerankan.

Pembelajaran secara teori dilakukan menggunakan media visual (gambar) melalui Liquid Crystal Display (LCD) yang terdapat di masing-masing kelas. Penggunaan media visual tentang suatu bentuk tari, baik penari serta gerakan yang dilakukan akan lebih jelas dipahami siswa. Media visual akan lebih dapat membuat para siswa untuk lebih mengetahui detail dari bentuk gerak, kostum serta properti (alat) yang digunakan oleh penari.

Pelaksaan praktek tari ketersediaan ruang praktek yang luas adalah faktor penting. Keterbatasan ruang praktek jelas akan mempengaruhi berlangsungnya pembelajaran secara praktek, tetapi dapat merangsang pengembangan metode pembelajaran yang digunakan oleh guru. Keterbatasan ruang praktek ini, guru membagi kelas menjadi dua bagian yaitu siswa putra dan siswa putri agar materi dapat disampaikan dengan baik.

Peneliti memilih SMP Negeri 1 Mlonggo sebagai objek penelitian karena secara ilmiah di SMP Negeri 1 Mlonggo, memiliki seorang guru seni tari yang berkompeten dalam bidangnya. Beliau sarjana pendidikan seni tari dan jelas memiliki basic menari dan mengajar dengan baik. Pembelajaran seni tari di SMP Negeri 1 Mlonggo cukup berkembang karena siswa diberi satu bentuk tari secara utuh. Penggunaan metode pembelajaran seni tari di SMP Negeri 1 Mlonggo cukup berbeda karena pemberian materi praktek untuk siswa putra dan siswa putri berbeda melihat dari kondisi ruang praktek yang terbatas. Metode pembelajaran yang diterapkan dibantu dengan penggunaan media audio visual sehingga pembelajaran seni tari secara teori dan praktek dapat disampaikan kepada siswa dengan baik dan jelas. Para siswa mendapatkan pembelajaran seni tari tidak semata-mata merupakan suatu hiburan melainkan mereka mendapat pengetahuan berkesenian yang baik akan kesenian yang ada di sekitar mereka.

Berpijak dari proses pembelajaran yang diterapkan diatas, peneliti ingin mengetahui bagaimana proses pembelajaran seni tari yang berlangsung di SMP Negeri 1 Mlonggo secara khusus pada kelas VII $\mathrm{D}$ dengan melihat dari metode dan media yang digunakan oleh guru pengampu seni tari, baik pembelajaran secara teori di ruang kelas dan praktek di ruang praktek. Perlu kiranya peneliti lebih dalam mengetahui 
proses pembelajaran seni tari di SMP Negeri 1 Mlonggo pada kelas VIID.

\section{Pembelajaran}

Pembelajaran mengandung makna adanya kegiatan mengajar dan belajar, dimana pihak yang mengajar adalah guru dan yang belajar adalah siswa yang berorientasi pada kegiatan mengajarkan materi yang beorientasi pada pengembangan pengetahuan, sikap dan ketrampilan siswa sebagai sasaran pembelajaran

\section{Perencanaan Pembelajaran}

Perencanaan pembelajaran
merupakan proses yang diatur
sedemikian rupa menurut
langkah-langkah tertentu baik berupa
penyusunan materi pengajaran,
penggunaan media, maupun model
pembelajaran agar pelaksanaannya
dapat berjalan dengan optimal.
Perencaan pembelajaran terdiri dari
Silabus dan RPP (Hernawan 2007:49).

\section{Komponen Pembelajaran}

Pembelajaran terdiri dari beberapa komponen yaitu peserta didik, guru, tujuan pembelajaran, proses pembelajaran, langkah-langkah pembelajaran, metode pembelajaran, media pembelajaran, kurikulum, bahan pembelajaran, dan ruang pembelajaran yang kondusif (Atwi Suparman 2012:38).

\section{Pembelajaran Seni Tari}

Tari adalah gerak indah oleh anggota tubuh yang mempunyai maksud dan sesuai dengan iringan musik pengiring. Ruang lingkup tari meliputi pengetahuan wiraga, wirama, dan wirasa (Syafi'i 2003:8, dalam Rakanita 2012). Pembelajaran seni tari merupakan salah satu bagian dari kehidupan manusia. Seni tari dalam segi pendidikan merupakan kegiatan kreatif yang dapat menumbuhkan kreativitas seseorang yang mempelajari seni tari. Pendidikan seni di sekolah memiliki fungsi dan tujuan untuk mengembangkan sikap dan kemampuan agar siswa mampu berkreasi dan peka dalam berkesenian, atau memberikan kemampuan dalam berkarya dan berapresiasi seni. Pendidikan seni akan dapat memberikan kontribusi terhadap perkembangan pribadi siswa. Kontribusi tersebut berkaitan dengan pemberian ruang berekspresi, pengembangan potensi kreatif dan imajinatif, peningkatan kepekaan rasa, menumbuhkan rasa percaya diri, dan pengembangan wawasan budaya (Jazuli 2008:103).

\section{Media Pembelajaran}

Media pembelajaran adalah seluruh alat dan bahan yang dapat dipakai untuk tujuan pembelajaran. Pemakaian media pembelajaran dalam proses belajar mengajar dapat membangkitkan keinginan dan minat yang baru, membangkitkan motivasi dan rangsangan kegiatan belajar, bahkan membawa pengaruh-pengaruh psikologis terhadap siswa, selain dapat membangkitkan motivasi dan minat siswa, media pembelajaran juga dapat membantu siswa meningkatkan pemahaman, menyajikan data dengan menarik dan terpercaya, memudahkan penafsiran data, dan memadatkan informasi (Arsyad 2008: 16).

\section{METODE}

Penelitian ini menggunakan metode kualitatif dengan pendekatan pedagogik. Sasaran penelitian siswa kelas VII D SMP Negeri 1 Mlonggo. 
Teknik pengumpulan data yang digunakan dalam penelitian ini adalah observasi, wawancara, dokumentasi dan analisis data. Pada teknik analisis data peneliti menggunakan tiga alur kegiatan yang harus dilakukan yaitu: mereduksi data, menyajikan data, serta menarik kesimpulan dalam proses pembelajaran yang berlangsung.

\section{HASIL DAN PEMBAHASAN}

\section{Gambaran Umum Lokasi Penelitian Letak Dan Sejarah SMP Negeri 1 Mlonggo}

Sekolah menengah pertama (SMP) Negeri 1 Mlonggo berdiri pada tahun 1983 menempati lahan seluas $20.000 \mathrm{~m}^{2}$ yang tepatnya di jalan Jepara-Bangsri KM.7 Mlonggo Kabupaten Jepara. Sesuai dengan keadaan geografisnya bahwa SMP Negeri 1 Mlonggo berada di wilayah Kabupaten Jepara dengan sebelah Utara dan Barat berbatasan dengan Jalan Kampung Warga Mlonggo, sebelah Selatan berbatasan dengan SMA Negeri 1 Mlonggo, dan sebelah Timur berbatasan dengan Jalan Raya Jepara-Bangsri. SMP Negeri 1 Mlonggo berjarak $12 \mathrm{~km}$ dari pusat kota, dan mempunyai nomor statistik sekolah 201032007038. Jarak yang ditempuh dari Unnes ke SMP Negeri 1 Mlonggo $72 \mathrm{~km}$ dengan waktu 2 jam 26 menit. SMP Negeri 1 Mlonggo berdiri pada tahun 1983 merupakan sekolah negeri di kecamatan mlonggo. Akreditasi pada tahun 2010 mendapatkan nilai 93 (A). berdasarkan kondisi lingkungan sekolah SMP Negeri 1 Mlonggo cukup baik, dilihat dari tingkat kebersihannya, pengaturan sanitasi, jalan penghubung menuju sekolah sangat mudah karena merupakan jalan utama Kabupaten Jepara menuju Kabupaten Pati dimana kendaraan umum sangat mudah didapat untuk akses siswa menuju sekolah selain diantar oleh orang tua mereka. Meski berada dipinggir jalan raya, suasana sekolah tidak bising karena ruang kelas tidak langsung dekat dengan jalan raya.

\section{Tenaga Pendidik/ Guru SMP Negeri 1 Mlonggo}

Tenaga pendidik di SMP

Negeri 1 Mlonggo hampir seluruhnya adalah PNS yang tentunya sudah berpengalaman dalam kegiatan belajar mengajar. Guru tetap berjumlah 36 orang, guru tidak tetap berjumlah 7 orang. Guru pengampu mata pelajaran seni tari di SMP Negeri 1 Mlonggo meruapakan guru pengampu yang memiliki wewenang dan latar belakang sebagai guru bidang setudi seni tari. Dwi Rumei yang biasanya dipanggil Bu Mei adalah lulusan

SMKI Surakarta pada tahun 1995, melanjutkan pendidikan SI jurusan seni tari di UNY lulus pada tahun 1999. Ibu Dwi Rumei menjadi PNS pada tahun 2005 dan pertama kali menjadi PNS mendapat penempatan di SMP Negeri 2 Kembang Kabupaten Jepara selama 3 tahun, kemudian melakukan mutasi di SMP Negeri 1 Mlonggo pada tahun 2008 bulan Juli hingga sekarang. Ibu Dwi Rumei sudah mendedikasikan ilmu di SMP Negeri 1 Mlonggo hampir 8 tahun. Pengalaman belajar mengajar yang cukup banyak diperoleh atau didapat melalui pengabdian Ibu Dwi Rumei, S.Pd di SMP Negeri 1 Mlonggo.

Sarana dan Prasarana di SMP 


\section{Negeri 1 Mlonggo}

Bangunan gedung di SMP Negeri 1 Mlonggo berdiri diatas tanah seluas $20.000 \mathrm{~m}^{2}$. SMP Negeri 1 Mlonggo mempunyai 24 kelas yang terdiri jumlah peserta didik 947 . Kelas VII sebanyak 8 kelas, kelas VIII sebanyak 8 kelas dan kelas IX sebanyak 8 kelas. Ruang kelas SMP Negeri 1 Mlonggo merupakan kelas yang sudah cukup nyaman bagi siswa, masing-masing kelas senantiasa dijaga kebersihannya melalui piket dari siswa di setiap kelas agar pada saat pembelajaran berlangsung kondisi kelas nyaman. Kebersihan kelas yang senantiasa dijaga salah satu faktor yang sangat mendukung keberhasilan siswa mencapai hasil belajar yang maksimal. Selain ruang kelas, juga terdapat ruangan-ruangan praktek atau kantor, seperti ruang kantor kepala sekolah, ruang kantor guru, ruang tata usaha, ruang UKS, ruang OSIS, ruang multimedia, Lab. IPA, Lab. Fisika, perpustakaan, ruang $\mathrm{BK}$, ruang ganti, ruang kesenian, mushola, gudang, ruang menjahit, WC serta kantin sekolah

\section{Pembelajaran Seni Tari di Kelas VII D SMP Negeri 1 Mlonggo Persiapan}

Pembelajaran seni tari merupakan pembelajaran yang membutuhkan ketrampilan dan minat yang kuat dalam mengikutinya. Seorang guru seni tari harus pandai dalam menarik perhatian siswa untuk giat dan tekun mengikuti mata pelajaran seni tari, dan di setiap tatap muka guru harus mempersiapkan diri memberikan materi dengan cara yang bervariatif dalam mengikuti pelajaran seni tari.

Pada tahap persiapan, guru mempersiapkan dan menyusun perangkat kegiatan pembelajaran semester genap seperti: Program Tahunan (Prota), Program Semester (Promes), Silabus, Rencana Pelaksanaa Pembelajaran (RPP), yang dibuat bersama berdasarkan hasil Musyawarah Guru Mata Pelajaran (MGMP) Seni Budaya Kabupaten Jepara.

Hasil MGMP Seni Budaya Kabupaten Jepara, pelaksanaannya disesuaikan dengan Kurikulum Tingkat Satuan Pendidikan (KTSP) SMP Negeri 1 Mlonggo, juga disesuaikan dengan Silabus dan Rencana Pelaksanaan Pembelajaran (RPP) yang diterapkan oleh guru seni tari di SMP Negeri 1 Mlonggo.

RPP (Rencana Pelaksanaan Pembelajaran) yang digunakan dalam semester ganjil ini dengan Standar Kompetensi: Mengapresiasi Karya Seni Tari dan Kompetensi Dasar ada dua yaitu: 1) Mengidentifikasi jenis karya seni tari unggal daerah setempat, 2) Menampilkan sikap apresiatif terhadap keunikan seni tari tunggal daerah setempat. Silabus yang digunakan dalam semester ganjil ini dengan standar kompetensi dasar ada dua yaitu: 1) Mengapresiasikan karya seni tari, 2) Mengekspresikan diri melalui karya seni tari. Lebih lengkapanya RPP dan Silabus terlampir pada halaman lampiran.

\section{Pelaksanaan}

1. Peserta didik

Penelitian ini mengacu pada peserta didik kelas VII secara umum, akan tetapi untuk pengamatan secara khusus penelitian di fokuskan hanya pada satu kelas yaitu kelas VII D. Pemilihan kelas VII D karena alasan kelas VII D merupakan kelas 
unggulan. Kenyakan dari peserta didik yang berada di kelas VII D merupakan peserta didik yang cukup aktif.

\section{Guru}

Guru pengajar seni tari yang memiliki pengalaman mengajar yang sudah cukup lama, menjadikan salah satu faktor pembelajaran seni tari dapat dilaksanakan dengan baik. Guru seni tari Ibu Dwi Rumei sangat kreatif dalam mengembangkan metode pembelajaran. Ibu Dwi Rumei selalu melihat kondisi yang terjadi di kelas, sehingga metode yang digunakan dapat menjadikan peserta didik mudah dalam menerima pembelajaraan. Faktor guru yang senantiasa menggunakan metode yang bervariatif merupakan modal utama pembelajaran di kelas dapat berjalan dengan menyenangkan.

\section{Tujuan Pembelajaran}

Pembelajaran yang sesuai dengan kurikulum yang digunakan merupakan dasar pembelajaran dilaksanakan. Kurikulum yang digunakan merupakan cara kegiatan belajar mengajar dapat memiliki tujuan. Sesuai dengan kurikulum tujuan pembelajaran akan dapat dicapai dengan ukuran penilaian tertentu untuk mendapat hasil yang maksimal dalam pembelajaran seni tari di kelas VII D.

4. Proses pembelajaran

Proses pembelajaran yang berlangsung di kelas VII D dapat dilaksanakan dengan baik. Pembelajaran secara teori dapat diterima dengan baik oleh peserta didik begitupun dengan pembelajaran secara praktek. Proses pembelajaran dengan pemanfaatan LCD di kelas VII D sangat membantu para peserta didik untuk lebih memahami materi begitupun dengan guru yang menyampaikan materi pembelajaran seni tari. Pembelajaran seni tari tidak dapat hanya guru menggunakan metode ceramah dan demonstrasi yang terkadang membuat peserta didik cenderung bosan dalam menerima materi. Pemanfaatan LCD peserta didik diajak untuk dapat melihat video pembelajaran seni tari dengan melihat bentuk tarian secara langsung. Ragam gerak, kostum, dan rias akan dapat jelas dan lebih mudah untuk dipahami.

5. Metode Pembelajaran

Metode yang guru seni tari gunakan dalam pembelajaran seni tari adalah metode ceramah dan demonstrasi. Metode ceramah banyak dilakukan kettika guru sedang menjelaskan materi secara teori. Metode demonstrasi dilakukan untuk memperkuat penjelasan-penjelasan yang telah dipaparkan oleh guru dalam menjelaskan materi. Metode demonstrasi akan diperjelas dengan peserta didik melakukan pembelajaran praktek di ruang praktek karena materi seni tari tidak hanya secara teori saja melainkan ada aplikasi dengan mempraktekkan materi yang telah disampaikan.

6. Media Pembelajaran

Sesuai dengan sarana dan prasarana yang sekolah berikan, media yang dimanfaatkan adalah ketersediaannya LCD di setiap kelas yang memungkinkan guru seni tari menggunakan media audio visual dengan melihat tayangan video pembelajaran materi tarian.

7. Kurikulum

Kurikulum yang digunakan masih menggunakan kurikulum KTSP.

8. Langkah-langkah Pembelajaran 
Pembelajaran seni tari yang dilakukan di kelas VII D diawali dengan pembukaan dimana peserta didik memberi salam agar kondisi kelas lebih nyaman. Kegiatan selanjutnya adalah kegiatan inti dimana guru menyampaiakan materi baik secara teori dan juga secara praktek sesuai dengan waktu dalam setiap pertemuan. Kegiatan penutup dilakukan dengan pengulangan materi pada hari itu baik dengan ringkasan materi atau guru memberi pertanyaan-pertanyaan ringan kepada peserta didik.

9. Bahan Pembelajaran

Bahan pembelajaran didapat dari buku panduan yang dimiliki peserta didik dan guru, serta dari video pembelajaran yang diberikan oleh guru kepada siswa tentang materi tari Candik Ayu dan Jaranan.

10. Ruang Pembelajaran yang Kondusif

Ruang yang disediakan oleh SMP Negeri 1 Mlonggo dapat dikatakan ruanag yang kondusif karena setiap ruang memiliki LCD dan SMP Negeri 1 Mlonggo juga memiliki ruang praktek yang cukup untuk peserta didik dapat melakukan pembelajaran secara praktek, meski praktek yang dilaksanakan harus bergantian.

\section{Proses Pembelajaran Seni Tari Pada Siswa Kelas VII D di SMP Negeri 1 Mlonggo}

\section{Pendahuluan}

Pembelajaran dalam kegiatan pendahuluan menerapkan sikap disiplin kepada peserta didik dengan selalu mengucapkan salam di setiap pembelajaran awal akan dimulai. Peserta didik berdiri di tempat duduk masing-masing dan mengucapkan salam bersama-sama kepada guru yang masuk ke kelas. Penerapam hal dalam memberi salam adalah bentuk sikap displin dan meningkatkan sopan santun peserta didik kepada guru yang akan menyampaikan pembelajaran.

2. Inti

Pelaksanaan pembelajaran seni tari dengan menggunakkan media audio visual yaitu melalui LCD untuk menampilkan video pembelajaran dari laptop yang dimiliki oleh guru seni tari Ibu Dwi Rumei.

3. Penutup

Kegiatan penutup dilakukan dengan beberapa hal diantaranya dapat dengan mengulas materi yang disampaikan pada hari itu ataupun dengan pemberian pertanyaan-pertanyaan ringan mengenai materi yang disampaikan pada hari itu.

\section{Proses Pembelajaran Seni Tari Dengan Menggunakan Media Audio Visual Pada Kelas VII D SMP Negeri 1 Mlonggo}

Proses

observasi

pembelajaran dilakukan dengan pengamatan sebanyak $4 \mathrm{x}$ pertemuan tatap muka di kelas untuk materi teori dan di ruang praktek untuk materi praktek. Observasi pembelajaran meliputi kegiatan pendahuluan, kegiatan inti, dan kegiatan penutup. Pembelajaran seni tari yang dilakukan dengan materi yang berbeda untuk peserta didik putra dan putri merupakan tantangan tersendiri untuk guru seni tari agar peserta didik dapat menerima materi sesuai dengan kemampuannya. Pembedaan materi yang dilakukan oleh guru seni tari merupakan bentuk motivasi agar peserta didik dapat lebih minat dalam mengikuti pembelajaran serta 
pengembangan metode pembelajaran yang lebih bervariasi. Berikut hasil observasi dalam $4 \mathrm{x}$ pertemuan dalam pembelajaran seni tari di Kelas VII D SMP Negeri 1 Mlonggo.

Pada setiap pertemuan terdiri dari kegiatan pendahuluan, inti dan penutup. Hasil dari observasi peneliti, kegiatan belajar mengajar dimulai dari penyampaian materi secara teori di dalam kelas dengan metode demonstrasi oleh guru seni tari. Pemberian materi awal dengan demonstrasi memberikan penjelasan secara umum mengenai tari tunggal daerah setempat serta materi tari secara khusus yang akan dipelajari oleh kelas VII khususnya kelas VII D.

Proses Belajar Mengajar Pertama (15 Agustus 2015)

Guru menyampaikan materi secara teori di kelas dengan metode demonstrasi dengan pembahasan awal penyampaian RPP dan Silabus kemudian dilanjutkan dengan pengertian tari secara umum serta penegrtian tari tunggal daerah setempat. Pada kegiatan penutup guru seni tari memberikan tugas tertulis.

Proses Belajar Mengajar Kedua (29 Agustus 2015)

Penyampaian materi dilakukan dengan penggunaan media audio visual dengan menampilkan video pembelajaran tari Candik Ayu dan tari Jaranan. Peserta didik mengamati setiap gerakan dan kostum setiap penari.

\section{Proses Belajar Mengajar Ketiga (12 September 2015)}

Peserta didik putri melakukan pembelajaran tari Candik Ayu secara praktek di ruang praktek dan peserta didik putra mengerjakan tugas yang diberikan oleh guru seni tari dengan baik di ruang kelas.

\section{Proses Belajar Mengajar Keempat (19 September 2015) \\ Peserta didik putra} melakukan pembelajaran tari Jaranan secara praktek di ruang praktek dan peserta didik putri mengerjakan tugas yang diberikan oleh guru seni tari di ruang kelas dengan baik.

Evaluasi yang digunakan untuk Mengetahui Hasil Belajar Peserta Didik

Bentuk evaluasi dalam pembelajaran seni tari di SMP Negeri 1 Mlonggo yaitu bentuk soal dan bentuk penyajian. Evaluasi bentuk soal yang dimaksud adalah guru memberikan soal-soal yang terdiri dari soal essay atau soal pilihan ganda mencakup materi yang telah disampaikan guru, guru memberikan waktu untuk mengerjakan dan dikumpulkan saat durasi waktu telah habis, sedangkan bentuk penyajian adalah peserta didik menyajikan tarian yang telah dipelajari dan disajikan dalam bentuk kelompok atau individu. Evaluasi untuk materi teori dilakukan di dalam kelas, sedangkan evaluasi praktek tari dilakukan di ruang praktek seni tari.

Faktor yang Mendukung Keberhasilan Penggunaan Media Audio Visual Dalam Pembelajaran Seni Tari Kelas VII D di SMP Negeri 1 Mlonggo

1. Faktor pendukung

a. Faktor guru

Guru memiliki dasar pendidikan seni tari yang sangat baik sehingga mampu memberikan 
pembelajaran seni tari dengan baik. Materi tari Candik Ayu dan Jaranan dapat disampaikan kepada peserta didik khususnya kelas VII D dengan baik.

\section{b. Faktor peserta didik}

Faktor peserta didik dapat mendukung belajar mengajar seni tari, dapat dilihat pada saat pembelajaran seni tari dilakukan dengan antusias peserta didik mengikuti, memperhatikan, dan mempraktekkan gerak yang telah disampaikan oleh guru. Guru pengampu pelajaran seni tari mulai menggunakan media audio visual untuk memancing keaktifan dan memotivasi peserta didik dalam pembelajaran seni tari. Di kelas VII D ini tidak hanya peserta didik putri saja yang menyukai pembelajaran seni tari, akan tetapi peserta didik putra pun cukup antusias dan senang menerima pelajaran seni tari dan mempraktekkan dengan baik.

\section{c. Faktor sarana dan prasarana}

SMP Negeri 1 Mlonggo mempunyai ruang praktek seni tari khusus. Pembelajaran seni tari di SMP Negeri 1 Mlonggo prestasi menari peserta didik meningkat adanya sarana dan prasarana yang mendukung. Penyediaan LCD di setiap kelas sangat mendukung pembelajaran khususnya pembelajaran seni tari yang tidak hanya disampaikan secara teori saja melainkan sangat membantu dalam pembelajaran praktek. Sarana dan prasarana di dapat dari anggaran rutin tahunan sekolah yang diadakan setiap awal tahun pelajaran baru.

\section{d. Faktor fasilitas peserta didik di rumah}

Fasilitas belajar peserta didik yang secara pribadi dan bisa digunakan untuk belajar di rumah seperti LKS Seni Budaya. Adanya fasilitas belajar peserta didik dirumah akan lebih mempermudah peserta didik untuk belajar dan memahami materi yang disampaikan guru di sekolah.

2. Faktor Penghambat

a. Faktor guru

Pemanfaatan waktu yang kurang baik oleh guru dalam proses pembelajaran seni tari sehingga materi yang diberikan kurang maksimal, apalagi jika pembelajaran seni tari saat praktek, pemanfaatan waktu yang harus diperhitungkan dengan baik, karena sering kali guru kekurangan waktu untuk praktek tari.

\section{b. Faktor peserta didik}

Peserta didik masih merasa kesulitan dalam menghafal gerakan tarian disebabkan peserta didik tidak semua memiliki fasilitas belajar secara pribadi yang bisa digunakan untuk belajar setiap saat di rumah, padahal dengan adanya fasilitas belajar di rumah peserta didik akan lebih mudah memahami materi yang telah disampaikan guru di sekolah khususnya materi praktek. Fasilitas belajar siswa yang masih kurang yaitu kepemilikan kaset-kaset tape maupun $C D$ pembelajaran tari-tarian, tetapi jika kaset dan $C D$ bisa dimiliki peserta didik, peserta didik akan mudah untuk mempelajari di rumah dan akan memudahkan siswa dalam menghafal materi tarian.

\section{c. Faktor sarana dan prasarana}

Fasilitas yang digunakan dalam pembelajaran seni tari ruang praktek yang kurang luas, sehingga 
dalam proses pembelajaran peserta didik dalam mempraktekkan terlihat berdesak-desakkan/bersentuhan

dengan peserta didik yang lain, hal tersebut cenderung mengakibatkan peserta didik tidak konsentrasi saat praktek/menari.

\section{d. Faktor lingkungan dirumah}

Fasilitas belajar peserta didik yang masih kurang yaitu kepemilikan kaset-kaset tape maupun $C D$ pembelajaran tari-tarian, tapi jika kaset dan $C D$ bisa dimiliki peserta didik, peserta didik akan mudah untuk mempelajari di rumah, dan akan memudahkan peserta didik dalam menghafal materi tarian.

\section{SIMPULAN}

Hasil penelitian yang telah diuraikan pada bab IV dapat ditarik simpulan bahwa proses pembelajaran seni tari di SMP Negeri 1 Mlonggo dibagi menjadi 2 tahap yaitu:

1) Tahap perencanaan : guru mempersiapkan RPP dan Silabus yang akan digunakan dalam pembelajaran seni tari di kelas VII D. Silabus yang digunakan memiliki dua kompetensi dasar yaitu: mengidentifikasi karya seni tari dan mengapresaisi karya seni tari. RPP yang digunakan memiliki dua kompetensi dasar: mengidentifikasi jenis karya seni tari tunggal daerah setempat dan menampilkan sikap apresiatif terhadap keunikan seni tari tunggal daerah setempat.

2) Tahap pelaksanaan: kegiatan pembelajaran dibagi menjadi tiga bagian utama yaitu pendahuluan, inti, dan penutup. Pada bagian pendahuluan peserta didik menunjukkan sikap displin didepan guru dan guru memberikan sikap apresiasi dengan pemberian motivasi keoada peserta didik. Pada bagian inti yang berkaitan dengan media audio visual, guru seni tari menyampaiakn materi tari di kelas VII D sesuai denga RPP danSilabus, kegiatan yang dilakukan pada saat pembelajaran menggunakan media dan metode yang telah disiapkan oleh guru seni tari setelah itu peserta didik mendemonstrasikan gerak tari yang telah dilihat dan dijelaskan dengan penggunaan media audio visual oleh guru pengampu seni tari pada pertemuan minggu yang lalu. Pada bagian penutup giri memberikan pertanyaan ringan atau pengulasan materi yang disampaikan pada pertemuan hari itu dan guru juga memberikan evaluasi dengan memberikan tugas atau PR kepada peserta didik untuk mempelajari materi tari di rumah yang disampaikan oleh guru sehingga pertemuan pembelajaran minggu depan dapat menjelaskan satu persatu materi tari yang kemarin yaitu tari Candik Ayu dan Jaranan.

Berdasarkan dari hasil penelitian dan pembahasan tentang Pembelajaran Seni Tari Dengan Menggunakan Media Audio Visual Pada Siswa Kelas VII D di SMP Negeri 1 Mlonggo, peneliti ingin memberikan saran sebagai berikut:

1) Bagi guru seni tari hendaknya terus mengembangkan metode pembelajaran lebih bervariasi lagi agar peserta didik lebih termotivasi dalam belajar seni tari dan peserta didik yang mumpuni akan dapat mewakili sekolah dalam lomba-lomba seperti FLS2N yang diadakan setiap tahun, materi yang lebih bervariatif akan lebih dapat menarik minat peserta didik dalam belajar seni tari. 
Oleh karena itu, para guru khususnya guru seni tari disarankan lebih kreatif dan inovatif.

2) Bagi SMP Negeri 1 Mlonggo, sarana dan prasarana seperti ruang praktek seni tari dapat diperluas atau dengan mengeluarkan gamelan yang berada di ruang praktek agar peserta didik dapat lebih bebas dalam bergerak pada saat praktek.

3) Bagi peserta didik diharapkan mampu memiliki kaset atau CD pembelajaran sendiri supaya peserta didik juga dapat mempelajari materi seni tari di rumah.

\section{REFERENCES}

Arsyad, Azhar. 2008. Media Pembelajaran. Jakarta: PT. Grafindo Persada.

Ayu, Rakanita Dyah. 2012. Proses Pembelajaran Seni Tari Dalam Mata Pelajaran Seni Budaya

Di SMP Negeri 1 Batangan Kecamatan Batangan Kabupaten Pati. Skripsi. Semarang: Universitas Negeri Semarang.

Hernawan, H.A dkk. 2007. Belajar dan Pembelajaran. Bandung: UPI PRESS.

Jazuli, M. 2008. Paradigma Kontekstual Pendidikan Seni. Semarang: UNNES University Press.

Mulyasa. 2006. Kurikulum Tinggi Satuan Pendidikan. Bandung: PT. Remaja Rosdakarya.

Soetopo, Sungkowo. 2004. Seni Tari Sebagai Muatan Lokal: Sebuah Alternatif. Semarang: Harmonia.

Suparman, Atwi. 2012. Desain Instruksional Modern. Jakarta: Erlangga.

Kusumadewi, L., \& Suharto, S. (2011). PENINGKATAN HASIL BELAJAR
SENI MUSIK DENGAN MEDIA AUDIO VISUAL MELALUI METODE BERVARIASI. Harmonia: Journal Of Arts Research And Education, 10(2). doi:http://dx.doi.org/10.15294/harmon ia.v10i2.63

Kusumastuti, E. (2011). PENDIDIKAN SENI TARI PADA ANAK USIA DINI DI TAMAN KANAK-KANAK TADIKA PURI CABANG ERLANGGA SEMARANG SEBAGAI PROSES ALIH BUDAYA. Harmonia: Journal Of Arts Research And Education, 5(1). doi:http://dx.doi.org/10.15294/harmon ia.v5i1.826

Rahayuningtyas, W., SDP, E., \& Wardhani, T. (2012). METODE PEMBELAJARAN

PENCANTRIKAN TERBIMBING DENGAN PEMANFAATAN AUDIO VISUAL. Harmonia: Journal Of Arts Research And Education, 11(1). doi:http://dx.doi.org/10.15294/harmon ia.v11i1.1500

Sulasmono, P. (2013). PENINGKATAN KEMAMPUAN VOKAL MELALUI METODE SOLFEGIO. Harmonia: Journal Of Arts Research And Education, 13(1). doi:http://dx.doi.org/10.15294/harmon ia.v13i1.2532

Ambarwangi, S., \& Suharto, S. (2013). PENDIDIKAN MULTIKULTURAL DI SEKOLAH MELALUI PENDIDIKAN SENI TRADISI. Harmonia: Journal Of Arts Research And Education, 13(1). doi:http://dx.doi.org/10.15294/harmon ia.v13i1.2535

Julia, J. (2016). The Role of 
Stakeholder in Fostering Traditional Art Awareness (A Case Study of Sundanese Local Song 'Cianjuran' Artist Training in Sumedang Regency West Java, Indonesia). Harmonia: Journal Of Arts Research And Education, 16(1), 87-94. doi:http://dx.doi.org/10.15294/harmon ia.v16i1.6005 